\title{
Environmental issues and international relations, a new global (dis)order - the role of International Relations in promoting a concerted international system
}

\author{
Questões ambientais e relações internacionais, uma nova \\ (des)ordem global - o papel das Relações Internacionais na \\ promoção de um sistema internacional concertado
}

http://dx.doi.org/10.1590/0034-7329201500110

JOANA CASTRO PEREIRA*

Rev. Bras. Polít. Int. 58 (1): 191-209 [2015]

\section{Introduction}

Today the world is more complex and unpredictable than ever before. Some say we live in a global disorder, in a chaotic international system, which even the most pessimistic ones were not able to predict after the end of the Cold War, since the current order is not unipolar, bipolar nor multipolar. There is still no world government-although an embryonic global governance system is emerging-and the fact that the US cannot rule the world the way it did in the 1990s, given the emergence of new powers in the international arena, seems to make it very difficult to identify present power relations. Furthermore, and paradoxically, globalization is fostering the resurgence of nationalism, because emerging economic powers seek to become political powers through national (re)affirmation and Western powers, namely in Europe, are beginning to tackle the rise of nationalist, racist and xenophobic forces due to the inability to cope successfully with the financial crisis. However, the international community faces many global problems, such as the ones related to the environment, and unless it cooperates to solve them the chaos might become much greater than what we have recently seen. I would dare to say that, taking into account the great disorder which can plague the international system in the absence of true cooperation strategies in the next years and decades, the current reality cannot be deemed chaotic, as what comes next has the potential to be orders of magnitude worse. Environmental issues, and the ones related to the

* Lusíada University, Porto, Portugal (mail@joanacastropereira.com). 
exploitation of natural resources in particular, are perhaps the most global, both in their essence and scale of action, and consequently the future of humankind largely depends on the ability to create an effective web of multilateral governance. Thus, one can argue the world will move towards a new global order or disorder based on environmental challenges and on our ability or inability to deal with them.

So, this article 1) underlines the complex characteristics of the current international system, focusing on the ambiguous effects of globalization; 2) exposes, through the review of the state of the art on the subject, the multidimensionality of environmental issues, with a special emphasis on natural resources (which are a very relevant element of the environment and, although they geographically belong to states, they belong, above all, in their nature, to all humankind, their management hence being a global responsibility), their growing importance for the development of the international system and the various security risks associated with them; and 3) highlights the role of the discipline of International Relations in studying the current dynamics of the international system and designing paths for cooperation and thus promoting a sustainable world.

\section{The hybrid international system of the twenty-first century: globalization as a "double-edged sword"}

The emergence of new global players, the growing interdependence and connections on a global scale, the erosion of the traditional division between national and international levels and the advent of a global governance system have led the discipline of International Relations to a growing focus on globalization, since relations among sovereign states are now insufficient to analyze and understand the political, economic and social dynamics of the current world.

Today there is a growing interdependence among states, which cannot be regarded as independent, autonomous and impermeable entities, such as "billiard balls" moving in a table, bumping against each other-a Westphalian characteristic - but rather as interdependent and interconnected actors in the international system, forced to work together on the basis of collective efforts and energies, something illustrated by the cobweb model of world politics. The great vulnerability of national economies to events that take place anywhere in the world, the massive use of digital technologies that allow individuals to communicate using uncontrollable means by governments, and the fact that the most prominent issues in the world, as the environmental ones, are inherently transnational, tell us that the Westphalian logic of the international system is increasingly questionable. Additionally, the emergence of an embryonic system of global governance, in which interests are articulated and aggregated, decisions are made and policies implemented, reveals that the international system of the twenty-first century holds post-Westphalian features (Zürn 2012). However, it would be a mistake to assume that this is a world without borders, because, in certain cases, which 
are enhanced by globalization itself, they are even more important at present, as shown, for example, in the strengthening of the state's role as an economic national agent and in the emergence of authoritarian powers in the international arena, such as China and Russia.

Sovereignty and domestic authority are changing, creating the concept of the disaggregated state (Heywood 2014): a more active state in a global world, full of overlays, in which the pursuit of national goals leads governments to participate in an extensive collaboration network, as well as in numerous forms of multilateral cooperation. Thus, sovereignty can be seen as the exercise of shared public power and authority among national, regional and global players, something that does not imply, in any way, a decline of the state. In fact, one can argue that there is a strengthening of the state's position in the international system. Sovereignty and authority are now increasingly exercised in a supraterritorial stage, even though territoriality is still politically significant (Biersteker 2012).

In a world full of economic and technological changes, and new forms of political and social mobilization, one also witnesses a very broad diffusion of power, associated with the rise of the BRICS and the MINTs (Stephen 2014; Durotoye 2014). Diffuse and uncertain power periods are difficult and dangerous, as the emergent powers may seek to challenge the status quo, while the established powers may try to stop the emerging countries through, for example, hard power strategies, which include the threats presented by traditional and new forms of military force (for instance, cyber warfare). Thus, some speak in the return to the Westphalian order of the international system, given the reevaluation of national security and the renewed concern about the outbreak of war. Nevertheless, one cannot neglect the complex nature of the current international order, which seems to face Westphalian challenges, such as the transition of power and the rise of new powers, and post-Westphalian challenges, such as changes in the balance between national and international levels, the material conditions of globalization and the growing importance of soft power and the legitimacy notion associated with it in terms of foreign policy. States now face global challenges, the resolution of which will require the development of processes that rely on a wide range of actors and various forms of governance, international law and political globalization. Furthermore, the emergence of new powers is an opportunity to boost cooperation, since there may be a better balance of power in the international system, so that dialogue and consultation seem to be the best and most realistic relationship strategies among the various powers (Pereira 2013). Otherwise, conflict may be the main characteristic of the system. Globalization is, therefore, a "double-edged sword," which creates a hybrid international system.

Although there is the emergence of a global governance stage and a growing interdependence between states, as well as a strong link between the achievement of national interests and the active participation in supranational arenas, it is clear that, regarding global issues-i.e. the ones which affect the international 
community as a whole and whose implications require global regulatory approach (Bhargava 2006) - international organizations and regimes in which states exercise their sovereignty have not an appropriate structure to manage and resolve such issues (Weiss 2012). The failure of the international society in addressing environmental problems such as climate change reflects the need for a reform in the international institutions of the UN system or even the creation of new ones, eminently global-oriented, able to manage and handle situations involving long-term issues. The emergence of new powers and global issues points to this path, in order to avoid tensions in the system. We are therefore facing a transition period in which the international system is marked by Westphalian and post-Westphalian characteristics and the world is faced with the possibility of the outbreak of tensions, conflicts and wars, but there is an unprecedented need for cooperation.

Environmental issues play a significant role in this matter, as they have features that enhance the onset of conflict, but at the same time call for global cooperation and coordination. The environment appears in the twenty-first century as a key issue in international relations, as it has enormous potential to turn the tide of globalization and the structure and the dynamics of the international system. Additionally, the way the international community manages the environment will profoundly affect the future of humankind.

\section{The environment as a multidimensional issue and a global security risk}

Globalization, population growth, economic and social development, natural resource exploitation and scarcity, climate change and urbanization are external drivers in the world today. In the Anthropocene, an era marked by the central role played by humankind in geology and ecology, global sustainability appears as a civilizational imperative.

\section{Environmental threats to security}

Environmental issues cut across a range of topics, namely security and economics, two areas of major importance to the state, and that is why, especially since 2007, they have come to play an important role in the international political agenda. The 2007 UN Security Council Meeting to discuss, for the first time, the climate change issue and the fact that this is a recurrent theme in the G20 Summits of the last years (Viola et al. 2013); major public panel sessions dedicated to the discussion of future natural resources extraction in a sustainable world, global food security, resilience to natural disasters, climate change, etc. at the 2014 Davos World Economic Forum (World Economic Forum 2014); and the China-US Climate Agreement announced in November 2014 are some of the many examples which demonstrate that environmental issues have played a prominent role on the international stage. 
Water wars, drug wars, diamond wars, oil wars— given the proliferation of resource wars in an era of scarcity-climate change, deforestation or pollution are now widely used expressions in international relations. The environment, in general, and natural resources, in particular, are deeply linked with security, which is one of the most controversial concepts of international politics. Although difficult to define, it seems fair to say that it involves in an objective sense the absence of threats to acquired values, in a subjective sense the absence of fear that such values will be attacked (Wolfers 1962 cited by Collins 2010), especially those which, if left unchecked, threaten the survival of a particular referent object (Williams 2008). In general terms, and according to Soroos (1997 cited by Barnett 2010), the concept of security can be defined as the assurance people have that they will continue to enjoy the things which are most important to their survival and well-being. In a changing world, environmental issues are now framed in the security concept, because traditional notions of security, focused on military security, lack relevance in a world of transnational phenomena capable of affecting a wide variety of human referent objects (Greaves 2012). Environmental security extends the concept of security by considering risks posed by environmental change to the things that people value (Barnett 2010). Such risks include climate change, deforestation, soil erosion and desertification, loss of biodiversity, air, land and water pollution, ocean acidification, depletion of the ozone layer, disruption of the nitrogen and phosphorus cycles, among others.

The Industrial Revolution, driven by technological development, agriculture, urbanization and the development of transport, as a response to population growth and the resulting increase in per capita demand, promoted consumption levels of goods and services that require, for example, large amounts of water, consumption levels which currently seem to be increasingly difficult to maintain. Climate change has exacerbated the situation ${ }^{1}$. Especially in the last 60 years, global water usage has increased twice as fast as the population, and the projected population growth for decades to come, as well as GDP growth, which coupled with the demand for energy, and food transformations in several developing countries point to a greater number of regions subject to water scarcity. Economic development and security are therefore threatened by poor management of water resources. Climate change and water are two inseparable realities, since the former has and will have a strong impact on water supply, while this is the main mediator of the effects of climate change on the economy, society and the environment, a relationship intrinsically linked to other sectors, including energy and food production.

Environmental protection, in other words, environmental security, covers food security, energy security, economic security and the access to fundamental

1 This is a major challenge if one takes into account that, in March 2015, for the first time since measurements began, the monthly global average concentration of carbon dioxide surpassed 400 parts per million (ppm). This is more than $120 \mathrm{ppm}$ since pre-industrial times and half of this only occurred since 1980 (National Oceanic and Atmospheric Administration 2015). 
natural resources, which leads us immediately to the concept of human security and reflects the fact that the environment is a multidimensional phenomenon. Human security involves environmental, economic, food, health, community, political and personal aspects, a concept that suggests security should also focus on individuals and not only on state-centric threats and national defense, and on the analysis of processes susceptible to undermine security, such as poverty, malnutrition, health, human rights, justice and access to goods and services. By this point of view, one can think of environmental insecurity as something associated with social injustice and inequality, which makes one think about the enhanced inequalities of globalization and, more specifically, of the overall economic policy (Schnurr and Swatuk 2012), something that reveals globalization is indeed a "double-edged sword." Violence derived from environmental problems involves exploitation, discrimination, unequal social and economic structures (Murshed 2014), problems that create an atmosphere of political, cultural or religious violence, so that an approach to the environment by the human rights perspective seeks to ensure that the natural world does not deteriorate to the point in which internationally accepted rights, such as life, property, health, having a family, a private life, access to culture and drinking water are at risk. In this sense, environmental protection is, at heart, an instrument to ensure all these rights. In other words, the question is founded on global environmental justice, which is not merely related to the mitigation of the anthropomorphic causes of climate change, biodiversity loss or toxic pollution of the ocean crisis. It also demands that adaptation measures do not further marginalize already vulnerable groups, because poverty kills (Soett 2012).

This is an example of how hybrid the international system of the twentyfirst century is, since the environment is responsible for a variety of problems and challenges, however, being a global issue, it can be seen as a tool to promote cooperation and solve a number of social problems around the world, hence prompting a concerted international system.

So, the threats of resource scarcity, global financial instability, inequality within and between countries, and environmental degradation jeopardize global security, a fact which shows us that the business-as-usual will be impossible to maintain. Changes in socio-economic, demographic and technological dynamics have increased the demand for a wide range of goods and services, which require a large amount of natural resources. It seems fair to say that a new global order is emerging, one that is deeply associated with the environment. Huge variations in water and food availability and growing competition over short and longer time-period objectives, as well as local and regional goals associated with water management and food production and use, will characterize the new world order (Calouste Gulbenkian Foundation 2014). Climate change, poverty and human rights are intrinsically associated to these challenges related to water and food, and natural resources in general, and it is not clear how to deal with them. 
Environmental threats are, in most cases, diffuse, indirect and international, created within and outside states, in a long process strictly related to economic activities, being part of economic, social and industrial systems and thus conflicting with the existing societal structures. Therefore, the major obstacle to the development of these structures is a cultural one. Protecting the environment involves a new perception of the relationship among states, markets and societies. Additionally, the long-term scale, the extent and nature of uncertainties and the unequal distribution of impacts and costs and political benefits over time and space associated with environmental protection make it difficult to analyze and solve environmental problems. These are inseparable from human security, as they are issues of social and environmental injustice, which involve unequal power relations and potential paths to emancipation, something that is not only associated with developing countries, but also with developed ones, although the first ones are subject to larger scale environmental problems. The truth is that human security hazards surpass state borders (Greaves 2012). For instance, agriculture is a key sector for humanity, being part of a high standard of living. In developing countries, agriculture is particularly important, since it provides employment and stability to several regions in the world, which means that these countries are extremely vulnerable to environmental degradation and climate change. Environmental protection and poverty are probably the two greatest challenges of this century, so the failure in solving one of them will undermine efforts to solve the other. Environmental challenges have the potential to affect the subsistence levels in most regions of Africa and various regions of Asia and Latin America, where poverty is a major problem, which may be synonymous with a growing political and economic instability, resulting in the proliferation of failed states, because many developing countries depend exclusively on natural resources. Breaks in food production, the spread of diseases, natural resource scarcity and migration processes may weaken the political ability of governments, leading to internal and regional conflicts (the competition for natural resources could inflame old ethnic and social tensions), paving the way to the spreading of radical ideologies and autocratic movements. In this context, the developed world will run a serious risk: trying to survive disasters, climate refugees and immigrants will threaten the borders of Europe and the US, which will pressure their economies and raise questions about sovereignty, citizenship and responsibility (Pereira 2013).

Concerning energy issues, which are also inseparable from the environment and natural resources protection, Legget (2013) highlights the possibility of an oil crunch within a few years. Consequently, he argues that this oil crash would lead to a financial crash:

History shows that oil demand drops in the global economic downturn following a financial crisis, releasing pressure on tight oil markets. But in a recessionary world today, or even a global depression, how long would that 
demand pressure dissipate for? The demand for oil in China, India and the major oil-producing countries is likely to be enduring (Legget 2013).

Mulligan (2012) follows a similar line of thought, asserting that there are three major crises facing international order: the initiation of (energy) resource wars, a near certainty of continued climate change and an economic crisis that has no evident solution. These crises are intrinsically linked, because climate change affects natural resources and exacerbates conflict potential, while putting at risk economic growth and development, a fundamental condition for addressing climate change effects and consequently protecting natural resources.

In a context of global depression, there is an enormous potential for the rise of authoritarian and semi-democratic plebiscitarian regimes across the world, which will seek economic prosperity for their nations no matter what. This would constitute an enormous global security risk. In fact, due to the financial crisis, Europe has already been witnessing an increase in the popularity of authoritarian political forces.

\section{Natural resources in a globalized world}

In 2014, the world has seen an abrupt fall of oil prices, due to a slowdown in the emerging countries and Europe's demand, and mostly due to the huge increase in the US production of non-conventional oil. Saudi Arabia reacted in a strategic long-term approach for avoiding the depletion of its oil reserve assets in face of a rapid development of non-conventional oil and renewable energy. The country's bet is to keep the oil price below the cost of production of a significant part of the producers of shale oil in the US. This reduction in oil prices is producing major effects in oil exporters dependent on a high price for keeping their national budget on balance-Russia, Venezuela, Iran, Iraq, Nigeria, Ecuador, etc.-; therefore, in most of these countries domestic social unrest is a significant threat. On the contrary, the US seems to be winning, since the country is benefiting from a large increase in its production and from being a major consumer (the country is importing cheaper oil). Some may interpret this development in prices as an aggression from the US against Russia, but howsoever there is an evident geostrategic tension in the international system, which constitutes a security risk.

With regard to exporting states, the existence of valuable natural resources heightens competition for control of the state and postpones the development of other sectors of economic life, given that, in most cases, these states have very weak political institutions, something that increases the likelihood of political authoritarianism and civil strife. It is important to underline that these conflicts begin as national security risks, but can quickly turn into international or global problems. Le Billon (2012) argues that resource allocations, operating practices, social rights and the discursive representations contribute to shape vulnerabilities 
and opportunities for the emergence of armed conflicts, which means that, in many cases, security problems are originated within a state, but have a large potential to surpass national borders and affect regional and international security. The idea of future conflicts over scarce resources and anthropogenic environmental change need to be considered in terms of particular geographies of vulnerability, threat and insecurity, as well as the new dynamics associated with globalization. So, traditional geopolitics perspectives over natural resources conflicts seem to be increasingly obsolete, inasmuch as they focus on resource supply for rich countries, pointing towards military invasions and national autarky, regarding natural resources as strategic imperatives based on state-centric perspectives which stress conflict risks fueled by ideas of shrinking resources and difficulties in supply. Given that one needs to study potential conflicts over resources in light of geographies of vulnerability, threat and insecurity, one also should be careful when analyzing geopolitical narratives about the threat of interstate resource wars due to the growing economies of Asia, for example, since they can promote them instead of avoiding them, simply because this is a simplistic view on the issue, which neglects the multidimensional nature of environmental issues and the need for global cooperation. As Frerks et al. (2014) argue, mono-causal approaches underlining the environment as the reason for war in the $21^{\text {st }}$ century have given way to a more modest approach in which environmental factors are not discarded as a conflict factor, but positioned into a broader and more complex framework (surpassing simple neo-Malthusian approaches) where scarcity directly leads to conflict.

One cannot assert the decay of geopolitics, one must admit that geopolitics is still relevant and important, but geopolitics cannot be the only perspective on environmental issues and natural resources in particular, since globalization itself has made the environment a global problem. Globalization and its global issues challenge the orthodox vision that emphasizes traditional geopolitics and the struggle for power among states, pointing to the importance of a new perspective, one which focus its attention on a geocentric perspective (in the politics of global social relations) or in a new geopolitics, given the increasing importance of soft power in international relations. Howsoever, this is another aspect that proves globalization is a "double-edged sword."

In the core of geopolitical thinking lies the realistic notion of the importance of achieving world order by means of a balance of power that seeks to prevent regional and global hegemony of rising powers, and some supporters of globalization suggest that world order can be achieved through greater economic and cultural interaction. So, according to this view, the Arab Spring events can be viewed both from the perspective of globalization and from the perspective of geopolitics. Globalization was important in disseminating ideas (through social networks, especially) and in spreading weapons through state borders, which challenged dictators across the Arab world. Also, external powers were asked to intervene either directly or indirectly, in order to establish a balance of power in 
a critical region of the world, one that can serve their interests (Heywood 2014). It was in Libya, where the ores and fuels account for $97 \%$ of exports and more than half of GDP, that the Arab Spring became, for the first time, violent, leading to NATO's intervention. One must keep in mind that outsiders have to deal with the problems associated with national conflicts over resources - problems such as illegal migration, terrorism, human or drug trafficking-becoming entangled in weak states trying to control these events, but that great power involvement may be aggressive and selfish, instead of defensive or altruistic (Hendrix and Noland 2014). The more assertive example of this is the US invasion of Iraq.

Thus, there are many narratives about competition over resources between the US and China (Klare 2013): they mention the effects of this competition for US-China relations, as well as possible tensions between China and countries such as Japan, India and Southeast Asian countries. As Reed (2014) emphasizes, "Chinese and US economies are intimately connected, while the two countries also compete for geostrategic influence at regional and global levels." Given its rise in economic, political and military terms, China may exert critical influence in countries full of valuable natural resources. Chinese influence in Africa is already a reality, because the country has surpassed the United States as the single largest provider of aid to the continent, and Chinese outward foreign direct investment is deeply targeted at the extractive sector. This resource boom can occasion a geopolitical confrontation between the United States and China (Hendrix and Noland 2014).

The question is: can China rise peacefully? So, China's rise is one of the reasons why the environment and natural resources are becoming more and more important in international relations. The other reasons encompass, for example, India, which is about to be the world's most populous country, having an emerging economy and being a political force stabilizing the South and Southeast regions of the Asian continent; Brazil, a major provider of commodities on world markets and an extremely important player in terms of global food security; or the Russian Artic, destined to be the heart of an enormous struggle of extractive industries and commercial and shipping centers. Besides, these are regions of high priority to the US; all of them are vulnerable to natural resource shocks and to the effects of climate change. "Small" events can have very significant effects across regions and the entire globe. According to Reed (2014), illegal trade in natural resources runs in the hundreds of billions of dollars annually. This illegal resource trade distorts international trade, weakens rules governing international commerce, and causes economic loss to producers and consumers in the United States.

Garrett and Piccini $(2012,5)$ also mention this fact, focusing on war economies, "a fertile business environment for international criminal networks and arms traffickers, who seek to exchange arms and other inputs in return for access to natural resource revenues or commercialization opportunities provided by high-value commodities." 
Another risk encompasses the fact that natural resource exporting states are empowered by higher prices, which makes them less amenable to international norms, namely those associated with global environmental governance and human rights, two global issues. In fact, these states tend to be economically highly integrated and they are associated with a low degree of political integration, in other words, they are very weakly linked to the global governance system. This fact can be explained by the fear of loss of sovereignty and autonomy, which reveals that we are living in "an international system under conservative hegemony" (Viola et al. 2013) $)^{2}$. Its smaller political integration complicates efforts to deal with issues that require collective global action, particularly those related to the environment. This dynamic is very clear in the negotiations to manage climate change, where the material interests of oil-exporting countries are at stake (Pereira 2013). Economic integration tends to reduce the likelihood of international environmental treaties ratification, while political globalization increases this probability. Therefore, energy exporting countries will hardly participate in the global governance of the environment. Additionally, since these countries are poorly integrated in political institutions, they are less likely to adhere to international norms associated with the use of force, both nationally and across borders, so their behavior is not constrained as it should be. Moreover, their weak political institutional links mean that especially energy resource exporters have fewer forums in which to peacefully solve their tensions with other countries. Consequently, these states are also isolated regarding conflict behavior.

However, despite the aggressive behavior of most exporting states, the truth is that their belligerence rarely culminates in armed conflict, something related to the post-Westphalian characteristics of war in the twenty-first century system, given that about $95 \%$ of armed conflicts since the second half of the 1980 s occurred within states and not among states (Heywood 2014), which reveals that, whilst international organizations are not designed to integrate the new powers' aspirations and natural resource exporters tend not to join political institutions, the embryonic global governance system of the twenty-first century has influenced states and its behavior in international arenas. Moreover,

because oil is a strategic resource, major powers invest significant resources in securing global supply lines and have incentives to prevent large-scale conflict in oil-producing countries that might result in global price spikes. [...] As a result of both domestic spending on defense in energy-exporting countries and their strategic significance for major powers, oil producers are less likely to experience wars (Hendrix and Noland 2014, 60).

2 According to the authors, climate change is the main civilizational vector of the present, which requires deep global governance, and it reflects the inability of international institutions to respond to the challenges of the twenty-first century. The system is defined as being "under conservative hegemony" due to the low degree of commitment to global governance and, above all, the climate commitment, since climate change requires a great level of cooperation. 
Nevertheless, these security guarantees can instigate exporting countries to act aggressively against other countries, namely those which are not exporters and don't have the same guarantees. Besides, the limited possibility of polluting the environment has the potential to inhibit resource extraction, another source of conflict, which is why the international community has to join forces to cooperate and manage the environment together through a geocentric perspective. Thus, natural resources, either in scarcity or in abundance, are a source of conflict and, at the same time, cooperation. Power and wealth have always been associated to warfare and cooperation, but since the environment belongs to the entire humankind and globalization gave birth to a number of global environmental challenges, which can only be addressed by all, cooperation will have to prevail in an effort to keep order in the international system. In fact, as Reed (2014) underlines, resource scarcities have obliged the governments of many countries to develop bilateral and regional resource management systems to prevent conflicts among neighbors while providing citizens with access to needed resources, which proves that environmental issues have the ability to promote cooperation.

According to Frerks et al. $(2014,14)$,

the emergence of conflicts is now often seen as related to the management of natural resources or more widely to the nature of resource governance regimes. (...) When managed properly, resource issues may help to foster a culture of environmental cooperation (...). Proper resource governance could not only help resolve resource conflicts, but also prevent them and lead to peaceful mutual relations.

This meets the idea exposed in section 2, since it corroborates that, regarding global issues, international organizations and regimes have not an appropriate structure to manage and resolve such issues, reflecting the need for a reform in international institutions or even the creation of new ones, eminently globaloriented. In fact, institutions of resource governance and the environment are rudimentary at best and they largely ignore the issue at the heart of the problem (Mildner et al. 2011).

Thereby, geopolitics and globalization are not two incompatible concepts, inasmuch as globalization opens many doors for international conflict, which should be considered in the light of geopolitics, but it also calls for unprecedented cooperation. Thus, the world may be heading for a new order or a new disorder. The growing interdependence among states and the global governance system "have borne fruit," but the international community is not free from the triggering of conflicts and wars. And here is where International Relations come in. 


\section{The path for cooperation: why global environmental issues "belong" to International Relations}

The environment is perhaps the most global and multidimensional issue in the international system and International Relations is a scientific field which benefits from a number of sciences and intends to combine knowledge from other disciplines with which the discipline itself develops, so it is the perfect field of study to analyze and build up a better understanding of the contemporary world. "Understanding the present world and its future evolution requires interdisciplinary knowledge. It requires an understanding of each of the drivers of change" (Calouste Gulbenkian Foundation 2014,1), which means that, concerning a multidimensional and global issue such as the environment, International Relations seems to be the most appropriate discipline to develop and provide to local, regional and international stakeholders a framework to understand global dynamics and its implications for the international community, as well as underline risks and find paths for cooperation. In the hybrid international system of the twenty-first century, where the world faces geopolitical challenges and the need to cooperate on a global scale, International Relations emerges as a highly relevant discipline. As we have seen, the world seems to be heading for a new global order or a new global disorder, deeply linked to the environment, which makes it extremely important to study this new global context, in order not to fall in global disorder.

Since International Relations study the diplomatic and strategic relations between or among states, cross-border transactions of all types and the multiple dimensions of contemporary globalization, it can contribute to building solutions for the new challenges of the twenty-first century, in other words, it can help promoting collective responses for problems that affect us all and for which there is no solution unless the international community joins forces, because the discipline has the potential to develop new knowledge about the political, economic and social dynamics of the present world. What happens inside of a state influences the global sphere and what happens globally affects the domestic domain: that is what globalization has created and has been exacerbating, and that is what we need to understand with the view to adapt to these new circumstances, avoiding conflicts and benefiting from the existence of common issues to promote a cooperative and concerted international system.

Nevertheless, there are some obstacles which have to be surpassed. Given that International Relations is a recent discipline, created after the end of the First World War, there is a very significant number of countries where this scientific field is still underdeveloped and underestimated, struggling to emancipate itself and conquer its very own place. Therefore, it seems fair to assert that, in International Relations, in many countries, there is still a very inadequate and insufficient body of knowledge, as well as inappropriate methodologies and scarce resources. Wherefore, scholars of International Relations need to work hard with the aim of developing 
the discipline, as well as proving its value and importance for a changing and interconnected world. This would be extremely important not only to develop a discipline which emerges as fundamental for understanding the present world, but also to promote scientific studies and its conclusions among elites (decision makers, stakeholders, etc.) —inasmuch as it would provide them with very relevant data to think up new policies or even propone these new policies - and the general public, because an informed population has greater power and greater capacity to influence decisions, as well as the direction their countries will follow, and consequently the international system, fostering and developing the idea of global citizenship.

With respect to the environment, all of the challenges already exposed in this article require, firstly, a holistic perspective on environmental insecurity, one that focuses on cause (global, economic, political, modernity), context (history, culture) and effects (health, natural disasters, slow cumulative changes, accidents, conflict) (Schnurr and Swatuk 2012) - International Relations has tools for developing this holistic perspective - and then a new way of living, a new philosophy of life. In other words, extremely efficient life styles in terms of resource use and global responses, something that asks for a global mindset change. This is another challenge for International Relations' scholars, given that, in this discipline, one finds the prevalence of a paradigm that does not link human society with its biological basis (the exception is traditional geopolitics), which is considered infinite. The truth is that the essential holistic paradigm still lies in the sideline of the discipline. However, because the protection of the environment constitutes a civilizational imperative, this paradigm must become predominant, in other words, International Relations' scholars have to develop this area towards a view which takes into account planetary boundaries. It is impossible to develop this scientific field without transforming it towards a total perception of the unbreakable link between social and natural spheres. We need to find a new way of articulating the local and global environmental insecurities and injustices that affects us all, but unequally so (Schnurr and Swatuk 2012). This requires a new approach to national interest. The international community must act keeping in mind global problems and, consequently, global interest, which is not contrary to national interest. We must face national interest in a new way, different from the traditional one: we have to build a concept of national interest which is strictly related to global interest, in the sense that it is impossible to achieve the most important domestic goals without thinking globally, without achieving the interest of humankind, and the environment seems to corroborate this fact. Thus, national and global interests are two sides of the same coin and not two incompatible realities, simply because globalization, one way or another, links our destinies.

Concerning water, for instance, we need to associate water management to global governance, in order to improve governance of the drivers causing pressures on water (climate change, population growth, economic development). Thirty to fifty percent of the food produced in the world is wasted, lost or converted (Calouste 
Gulbenkian Foundation 2014) and the production of energy is the second largest user of water, activities that put pressure on this vital resource and make it very difficult to fight against poverty in the most vulnerable regions of the globe and promote human rights. Taking into account the great civilizational challenge of climate change, the international community needs to "re-engineer the energy of nations" (Legget 2013), international leaders and citizens must converge and commit to provide a fair and efficient use of fundamental resources, as well as to develop the path for a green economy, which should be a priority in a globalizing world. Although the international community is aware of the existence of global commons, global responsibilities and common goals, the truth is that, in practice, responses are based on narrow and simplistic approaches to the problems. There are neo-Malthusian assumptions of the future, but they seem to be insufficient to trigger effective action, hence the importance of promoting the prevalence of a holistic paradigm in International Relations. Current constraints can be broken and there is no need to be Malthusian, since trends are not destiny. Changing contexts must be explored and it is vital to highlight that new opportunities are also emerging (Calouste Gulbenkian Foundation 2014).

This is what Klare $(2013,227)$ calls "the race to adapt," which is "a contest to become among the first to adopt new materials, methods, and devices that will free the world from its dependence on finite resource supplies. (...) Power and wealth will come (...) from mastery of the new technologies." The disregard for the development of technology was one of the biggest mistakes in Malthus' theory. However, one may not forget that the creation of an effective environmental global governance regime and the move towards a green and sustainable economy will require political will and action from the greatest powers of the international system, both with regard to its internal contexts, as for the transition to sustainability in the poorest countries. The international community can start with a global governance regime for the resource sector which level the playing field for populations, governments, and businesses and encourage greater transparency and improved management of natural resource wealth (Le Billon 2012). Thereby, scholars of International Relations have the potential and the duty to seek and propose new ways of global organization, holistic ones, because, as Hendrix and Noland $(2014,56)$ argue, membership in international organizations and political globalization have powerful implications for reducing international conflict behavior and increasing respect for human rights, since international institutions can be important shapers and transmitters of international norms." Furthermore, by renewing our sense of unity with the rest of Nature, we can imagine new ways of being and through cooperation and innovation we can achieve them (Calouste Gulbenkian Foundation 2014).

As we have seen, globalization and the emergence of new powers can create a climate of tension and conflict in the international system, but these processes also create a great opportunity to develop a regime of unprecedented multilateral 
co-operation. For this to happen, researchers of International Relations must study new ways of political integration, new institutions designed to face global longterm challenges and to embrace new emerging powers, inasmuch as the Western world cannot solve the twenty-first century problems alone and the Global South cannot achieve its most prominent goals without joining forces with developed countries of the North. Ultimately, this may pressure world leaders to rethink the very basis of capitalism (Legget 2013) —in other words, to develop a "sustainable capitalism" - which will affect our political and social structures. In a much more distant horizon, this could lead to a cosmopolitan perception of the international system, which would beat the current nationalist division of the world.

The capacity of International Relations to make use of a plethora of data and knowledge from other disciplines makes it the right area to study global, international, national, community and individual perspectives, with the aim of revealing the complexity behind environmental insecurity, prevent wars in the international system and create a new global order based on multilateral cooperation, promoted by the need to preserve our common environment.

\section{Conclusion}

Throughout this article I exposed the Westphalian and post-Westphalian characteristics of the hybrid international system of the twenty-fist century, arguing that globalization acts in ambiguous ways and that environmental challenges are an important part of these ambiguous and unpredictable effects of globalization. Through the review of the most up to date research on environment and natural resources in particular, I intended to reveal how environmental issues touch on a number of different areas and how they constitute a global security risk, as well as a great opportunity to move towards global cooperation, asserting that geopolitics and globalization are not incompatible, on the contrary, they are complementary concepts, which are fundamental for understanding the world's current complexity. Likewise, it was underlined why the environment is increasingly important in international relations. In a nutshell, I tried to demonstrate how a new global order is emerging and the ways in which the environment is shaping and might shape the world and social interactions on a global scale, arguing that International Relations, as a discipline, has the potential and the means to study this new global order and to propone to international leaders institutional reforms and cooperation paths. It is important that scholars of International Relations focus more and more on environmental challenges, given their increasing importance in the international system and their global essence, as well as their potential to foster cooperation.

The world is becoming multipolar and this doesn't mean the US is in decline, because it is not. The point is that other powers are emerging and therefore there will not be a hegemonic power, but a balance of power based on strong interdependence-in other words, through interdependence, globalization is 
promoting the geopolitical principal of balance-since these powers are getting closer to the US. Nevertheless, this multipolar world will only function if true and effective global governance institutions (either multilateral or plurilateral) are developed, inasmuch as a multipolar order demands dialogue. If conflict and war prevail, this order will be a game of losers and losers, especially concerning all the environmental challenges enumerated in this article. Thus, we will live a new global disorder. Recent trends point to an international system based on conflict and tension, marked by economic and political disjointedness, but there seems to be room for a concerted world in the long-term, perhaps with moderate growth rates and rising educational standards. In view of the emergence of new powers and global problems in the system, cooperation is the most appropriate resource to meet future challenges, given that the international agenda is growing wider every day. For instance, the increase in extreme weather events is one of the global challenges that require a concerted and cooperative action, so the climate issue may be one of the catalysts for a truly new global order. However, as I tried to explain throughout this article, this doesn't mean at all that disorder is "out of the table." We run a serious risk of being trapped in conflict and war. Scholars of International Relations have the potential to help finding answers for a world in transition.

\section{Bibliographic references}

Barnett, Jon. "Environmental Security." In Contemporary Security Studies, edited by Alan Collins, 218-237. New York: Oxford, 2010.

Bhargava, Vinay K. Global Issues for Global Citizens. Washington, DC: World Bank Publications, 2006.

Biersteker, Thomas J. "State, Sovereignty and Territory". In Handbook of International Relations, edited by Walter Carlsnaes, Thomas Risse and Beth A. Simmons, 245-272. London: Sage, 2012. Calouste Gulbenkian Foundation. Water and the Future of Humanity. Revisiting Water Security. London: Springer, 2014.

Collins, Alan. "Introduction: What is Security Studies?" In Contemporary Security Studies, edited by Alan Collins, 2-11. New York: Oxford, 2010.

Durotoye, Adeolu. “The MINT Countries as Emerging Economic Power Bloc: Prospects and Challenges”. Developing Country Studies 4, no. 15 (2014): 99-106. Accessed February 17, 2015. url: http://www.iiste.org/Journals/index.php/DCS/article/view/14420

Frerks, Georg, Ton Dietz and Pieter van der Zaag. "Conflict and cooperation on natural resources: justifying the CoCooN programme." In Conflicts Over Natural Resources in the Global South. Conceptual Approaches, edited by Maarten Bavinck and Lorenzo Pellegrini, 13-34. CRC Press, Taylor \& Francis Group: London, 2014.

Garrett, Nicholas and Anna Piccinni. Natural Resources and Conflict. A New Security Challenge for the European Union. Resource Consulting Services: London, 2012. 
Greaves, Wilfrid. "Insecurities of non-dominance: re-theorizing human security and environmental change in developed states." In Natural Resources and Social Conflict. Towards Critical Environmental Security, edited by Matthew A. Schnurr and Larry A. Swatuk, 63-82. London: Palgrave Macmillan, 2012.

Hameiri, Shahar and Lee Jones. "Rising Powers and State Transformation: The Case of China." European Journal of International Relations (2015): 1-27. Accessed May 6, 2015. url: http://ejt. sagepub.com/content/early/2015/04/16/1354066115578952.refs

Hendrix, Cullen S. and Marcus Noland. Confronting the Curse. The Economics and Geopolitics of Natural Resource Governance. Washington, DC: Peterson Institute for International Economics, 2014.

Heywood, Andrew. Global Politics. London: Palgrave Macmillan, 2014.

Klare, Michael T. The Race for What's Left. The Global Scramble for the World's Last Resources. New York: Picador, 2013.

Le Billon, Philippe. Wars of Plunder. Conflicts, Profits and the Politics of Resources. London: Hurst, 2012.

Leggett, Jeremy. The Energy of Nations: Risk Blindness and the Road to Renaissance. Routledge: New York, 2013.

Mildner, Stormy-Annika, Solveig Richter and Gitta Lauster. Resource Scarcity — A Global Security Threat? SWP: Berlin, 2011.

Mulligan, Shane. "Official secrets and popular delusions: security at the end of the fossil fuel age?" In Natural Resources and Social Conflict. Towards Critical Environmental Security, edited by Matthew A. Schnurr and Larry A. Swatuk, 152-169. London: Palgrave Macmillan, 2012.

Murshed, Syed Mansoob. "New directions in conflict research from an economics perspective." In Conflicts Over Natural Resources in the Global South. Conceptual Approaches, edited by Maarten Bavinck and Lorenzo Pellegrini, 34-50. CRC Press, Taylor \& Francis Group: London, 2014.

National Oceanic and Atmospheric Administration. "Greenhouse gas benchmark reached". Oceanic and Atmospheric Research. May 6, 2015. Accessed May 29, 2015. http://research.noaa. gov/News/NewsArchive/LatestNews/TabId/684/ArtMID/1768/ArticleID/11153/Greenhousegas-benchmark-reached-.aspx

Pereira, Joana Castro. "Segurança e Governação Climáticas: O Brasil na Cena Internacional”. PhD diss., New University of Lisbon, 2013.

Reed, David. In Pursuit of Prosperity: U.S. Foreign Policy in an Era of Natural Resources Scarcity. Routledge: New York, 2014.

Schnurr, Matthew A. and Larry A. Swatuk. "Towards critical environmental security." In Natural Resources and Social Conflict. Towards Critical Environmental Security, edited by Matthew A. Schnurr and Larry A. Swatuk, 1-14. London: Palgrave Macmillan, 2012.

Stephen, Matthew D. "Rising Powers, Global Capitalism and Liberal Global Governance: A Historical Materialist Account of the BRICs Challenge." European Journal of International Relations 20, no 4 (2014): 912-938. 
Stoett, Peter. "What are we really looking for? From eco-violence to environmental injustice." In Natural Resources and Social Conflict. Towards Critical Environmental Security, edited by Matthew A. Schnurr and Larry A. Swatuk, 15-32. London: Palgrave Macmillan, 2012.

Viola, Eduardo, Matías Franchini and Thais Lemos Ribeiro. Sistema Internacional de Hegemonia Conservadora. Governança Global e Democracia na Era da Crise Climática. Sáo Paulo: Annablume, 2013.

Weiss, Thomas G. What's Wrong with the United Nations and How to Fix it. Cambridge: Polity Press, 2012.

Williams, Paul D. "Security Studies: An introduction”. In Security Studies: An Introduction, edited by Paul D. Williams, 1-10. New York: Routledge, 2008.

World Economic Forum. "World Economic Forum Annual Meeting 2014. The Reshaping of the World: Consequences for Society, Politics and Business". Geneva: World Economic Forum, 2014.

Zürn, Michael. "Globalization and Global Governance”. In Handbook of International Relations, edited by Walter Carlsnaes, Thomas Risse and Beth A. Simmons, 401-425. London: Sage, 2012.

Submitted on June 5, 2015

Accepted on June 16, 2015

\begin{abstract}
Is it possible to talk about the rise of a new global (dis)order founded on the challenges posed by environmental issues? Through the review of the state of the art on the subject, this article analyzes the growing importance of the environment, and natural resources in particular, in international relations; and aims to raise awareness among International Relations scholars to the potential positive impact of the development of the discipline in integration with global environmental change studies.
\end{abstract}

Keywords: environment; geopolitics; globalization; International Relations; natural resources; security.

\title{
Resumo
}

Será possível falar da emergência de uma nova (des)ordem global fundada sobre os desafios colocados pelas questões ambientais? Com base na análise do estado da arte, aborda-se a crescente importância do ambiente, e dos recursos naturais em particular, nas relações internacionais; e procura-se sensibilizar os académicos das Relações Internacionais para o potencial impacto positivo decorrente do desenvolvimento da disciplina em integração com os estudos relativos às mudanças ambientais globais.

Palavras-chave: meio ambiente; geopolítica; globalização; Relações Internacionais; recursos naturais; segurança. 